\title{
On Aristotle's Natural Limit
}

\author{
C. Tyler DesRoches
}

Whereas Socrates preached temperance and frugality, and drove a wedge between wealth and virtue, Aristotle argued that a moderate amount of wealth was an intrinsic element to pursuing the good life, at least for the pater familias. ${ }^{1}$ For Aristotle, there is a minimum amount of wealth required to avoid a life of toil and there is a maximum amount above which full happiness or eudaimonia cannot be achieved (Pol 1265a30-36). ${ }^{2}$

Scholars of ancient economic thought have construed this upper limit to money-making as Aristotle's "natural limit" (see, for example, Kern 1983, 507; Pack 1985, 391; César das Neves 2000, 650). S. Todd Lowry (1974, 60; 1987, 232-36) and Moses I. Finley $(1970,16)$ have considered the view that Aristotle's natural limit, and unlimited money-making generally, might be settled independently of the broader question of achieving the

Correspondence may be addressed to C. Tyler DesRoches, Department of Philosophy, University of British Columbia Vancouver Campus, 1866 Main Mall, Buchanan E 370, Vancouver, British Columbia, Canada V6T 1Z1; e-mail: t.desroches@alumni.ubc.ca. This research was partly funded by the Social Sciences and Humanities Research Council of Canada. An earlier version of this essay was presented at the 2012 History of Economics Society meeting at Brock University in St. Catharines, Ontario, Canada. I would like to thank Scott Anderson, Paul Bartha, Sylvia Berryman, Ian Brooks, Gilles Campagnolo, Ricardo Crespo, Tom Green, Michael Griffin, Andrew Irvine, Christine Katerynych, David Levy, Spencer Pack, Margaret Schabas, and three anonymous referees for their suggestions and comments.

1. Moses I. Finley ([1973] 1999, 36) claims that, for Socrates, wealth is "neither essential nor even necessarily helpful in achieving a good life."

2. All references to Aristotle's Politics refer to Benjamin Jowett's translation found in Jonathan Barnes's ([1984] 1995) edited volume, The Complete Works of Aristotle.

History of Political Economy 46:3 DOI 10.1215/00182702-2796197

Copyright 2014 by Duke University Press 
virtuous life. This essay argues that Aristotle's natural limit is imposed on all members of the human species capable of achieving the good life and that the virtuous master of any household (oikos) will wisely comply with the natural limit by acquiring and administering a sufficient amount of wealth to satisfy a necessary condition for attaining eudaimonia. This interpretation of Aristotle's natural limit, it should be noted, is aligned with those advanced by others, including Charles Griswold $(1999,266)$ and Scott Meikle (1995). Meikle (1995, 45), for example, contends that, for Aristotle, "the good life and its constitutive ends set the standards for deciding how much wealth is enough." However, Meikle does not go so far as to preclude the wealth-seeking path as coincident with a flourishing life. ${ }^{3}$ This essay argues that the very notion of a money-making eudaimôn is impossible for Aristotle and it explains why this is the case.

For Aristotle, there are several reasons why a human life committed to money-making is incompatible with achieving eudaimonia. First, he associates the unnatural money-maker's aim of accumulating an ever-larger pile of money with the life of pleasure, not the good life. Because Aristotle forcefully denies the hedonist identity thesis that the life of pleasure is the best life for humans, it is difficult to see how a life committed to the endless activity of commerce and trade beyond the needs of one's household can coincide with achieving eudaimonia. It is also argued that, from the standpoint of Aristotle's Doctrine of the Mean, unnatural "wealth getting" (chrêmatistikê) is a misguided ambition-a vice, not a virtue. It is not, in any sense, the objective pursued by the practically wise, who act rightly because they possess the human excellences of theoretical wisdom (sophia) and practical wisdom (phronêsis). Excesses such as avarice reveal a defect in character, and if an individual can be eudaimôn only because his character is not defective, then actions directed toward endless money-making are, in the very least, discouraging for the prospective money-making eudaimôn. At worst, the individual who pursues money-making as an end in itself risks becoming a slave to what William James Booth $(1993,49)$ describes as the "invisible master" of pleonexia. This troubling possibility only amplifies the difficulties faced by a money-maker striving for the good life; after all, action directed toward acquiring unlimited riches can restrict or inhibit the attainment of other intrinsically valuable goods-goods that Aristotle argues are necessary for human flourishing, including friendship (philia), agency (praxis), and autonomy.

3. This statement, of course, does not imply that Meikle would disagree with the claim that a money-making eudaimôn is impossible for Aristotle. Indeed, he may well have considered it as a matter of course. 


\section{Aristotle's Natural Limit}

In book 1 of the Politics, Aristotle grapples with the topics of wealth and household management (oikonomikê). He asks whether money-making and oikonomikê are the same thing and responds in the negative, stating, "It is easy to see that the art of household management is not identical with the art of getting wealth, for the one uses the material which the other provides" (Pol 1256a9-11). ${ }^{4}$ This statement affirms Aristotle's instrumental notion of wealth insofar as chrêmatistikê is a part of good household management. For Aristotle, all means-ends relationships are limited by their ends, including the master's wealth acquisition for oikonomikê. He distinguishes between natural chrêmatistikê in the good sense, which is constrained by the needs of the household, and unnatural chrêmatistikê in the bad sense, which is unlimited and treats money-making and trade (kapêlikê) as ends in themselves (Meikle 1995, 47). On the subject of natural chrêmatistikê Aristotle states,

Of the art of acquisition ... there is one kind which by nature is a part of the management of a household, in so far as the art of household management must either find ready to hand, or itself provide, such things necessary to life, and useful for the community of the family or state, as can be stored. (Pol 1256b27-30)

Natural chrêmatistikê involves the master of a household acquiring and administering those useful objects of wealth that constitute "true wealth" or "true riches" in order to meet the needs of all household members, including the master, his wife, children, and slaves. Aristotle's disapproval of unnatural chrêmatistikê, however, does not imply opposition to all forms of money-making, but only those belonging to commercial and trade activities that are completely divorced from the ends of oikonomikê. Thus, if a person trades to make money and this activity is directed toward self-sufficiency, Aristotle does not condemn it, since it remains bound by oikonomike. ${ }^{5}$

4. It is worth noting that while Jowett's canonical work translates oikonomikê as an art, others have considered oikonomikê to be a practical science that aims at good action (see, for example, Miller 1995).

5. This creates a puzzle for Aristotle, since instances of unnatural chrêmatistike, those bound by oikonomike, are within the confines of the natural limit. In Marxian terms, C-M-C is natural and M-C-M' is unnatural (see Meikle 1995, 51-52). One way that Aristotle might have responded to this objection would be to maintain that instances of unnatural chrêmatistikê bound by oikonomikê only appear to be unnatural chrêmatistikê (M-C-M'). Since such activities are ultimately constrained by oikonomike, they are, in the long run, actually structured as C-M-C. 
In the Politics, Aristotle provides an account of the origins of currency and unnatural money-making. We are told that in ancient times individuals and households originally exchanged goods for goods in order to meet their natural needs and that this form of barter exchange was mutually beneficial for all parties involved. This natural process of bartering goods for goods for their use value, as opposed to their exchange value, eventually gave rise to the unnatural chrêmatistikê that is characteristic of retail trade. Unlike the natural acquisition of wealth, unnatural chrêmatistikê, or simply "money-making," describes actions directed toward the pursuit of unlimited riches. Unlike natural chrêmatistikê, which serves the needs of the household, money-making for its own sake is an artificial practice that involves acquiring unlimited riches and therefore extends acquisition beyond the true wealth required to administer a selfsufficient oikos.

The ancient Greek oikos was, for Aristotle, a natural and cooperative human association fully embedded in the wider polis. This composite entity comprised the physical property belonging to the oikos, the master, his wife, children, slaves, and hired labor. Invariably, the oikos was characterized by the superior parts ruling over inferior ones. This meant that husbands ruled over wives and masters ruled over slaves, as the soul ruled over the body (Nagle 2006; Roberts 2009). ${ }^{6}$

For Aristotle, the concept of "nature" has several different meanings (see Collingwood [1945] 1976, 81-85). In one sense, the concept denotes an inner principle of change that is characteristic of self-moving things. Unlike unnatural or artificial objects, natural objects are involved in a process of growth, change, and flux. ${ }^{7}$ Nature, in this sense, is deeply intertwined with how things behave when left to themselves, free from human agency. In another sense, "nature" denotes specific items that exist by nature, and not by any other causes. Aristotle has this sense of "nature" in mind when he reviles usury. As Joel Kaye $(1998,87)$ explains, "Aristotle believed usury was the most despicable and unnatural, because in the usurious loan, money, which was invented solely as an instrument of exchange, is made to generate itself, to give unnatural birth to itself." Money does not exist by nature, but by law or convention ( $N E$ 1133a30ff); usury is a particularly bad kind of unnatural chrêmatistikê because money was cre-

6. As Fred D. Miller $(1995,242)$ explains, “Aristotle's inegalitarianism is based on the alleged natural inferiority of whole classes of persons as defined by nationality, gender, and profession."

7. For much more on the detail of Aristotle's distinction between "natural" and "artificial," see Physics 2.1, 192b12-23. 
ated with a specific telos, to facilitate exchange. ${ }^{8}$ The charging of interest (tokos), which involves money begetting money, is unnatural because this activity is not in accordance with the end for which money was originally created. Therefore, Aristotle condemns the charging of tokos because this activity distorts the purpose of money.

In the Politics, Aristotle acknowledges the limitless activity of acquiring ever-more riches when he states,

Natural riches and the natural art of wealth-getting are a different thing; in their true form they are part of the management of a household; whereas retail trade is the art of producing wealth, not in every way, but by exchange. And it is thought to be concerned with coin; for coin is the unit of exchange and the limit of it. And there is no bound to the riches which spring from this art of wealth-getting. (Pol 1257b19-24)

As Meikle $(1994,28)$ observes, for Aristotle, a pile of riches can differ from another only in magnitude, and not qualitatively. Because money is a quantity, it has no limit; this is why Aristotle accepts that unnatural chrêmatistikê, even though it is a disparaged species of money-making, has no bound. But while Aristotle accepts the platitude that one can always add another coin to his pile of riches, he contrasts his position with that endorsed by the Greek Athenian statesman Solon. Aristotle states,

They are the elements of true riches; for the amount of property which is needed for a good life is not unlimited, although Solon in one of his poems says that

No Bound to riches has been fixed for man.

But there is a boundary fixed, just as there is in the other arts; for the instruments of any art are never unlimited, either in number or size, and riches may be defined as a number of instruments to be used in a household or in a state. (Pol 1256b30-36)

Aristotle appears to be using Solon's poem to establish that the tools of any art, including oikonomikê, are never infinite (apeiron). ${ }^{9}$ It is primarily from these the two passages (directly above) that scholars have attributed Aristotle with a natural limit. ${ }^{10}$ Others, however, have denied that Aristotle

8. Aristotle also recognizes that money can serve as a unit of account and a store of wealth.

9. This poem can be found in M. L. West's (1972) Iambi et Elegi Graeci (poem 13).

10. Lowry $(1974,1987)$ describes the historical dimension of Aristotle's natural limit. Lowry has argued that the consumption-oriented barter system of ancient Athens provided a natural limit on monetary accumulation for its own sake and that this system failed in part because of the metics (resident aliens), who were merchants interested in money accumulation above and beyond the use value of consumption goods. 
ever acknowledged such a limit. For example, in his Economy and Nature in the Fourteenth Century, Kaye $(1998,55)$ states, "If money were natural, [Aristotle] reasoned, then there would be a natural limit to the desire for riches. Since it was clear to him that this natural limit did not exist, he concluded that "retail trade is not a natural part of the art of getting wealth.'" Aristotle, however, was never so explicit, and it is not apparent that he actually reasoned this way. Although Aristotle agrees with Solon that riches, like all quantities, have an unlimited nature, he also appears to maintain that the true wealth of any oikos is limited to that set of useful goods required for the good life. As Charles Griswold $(1999,266)$ states, "Aristotle quotes Solon to the effect that wealth, and implicitly the desire for it, knows no boundary but replies that there is such a limit, namely that defined by the good life." William Kern $(1983,507)$ offers a similar interpretation when he states, "Wealth and external goods are a means to an end for Aristotle; as such there is some 'natural' limit to the needs of individuals as dictated by the ultimate good." Given the above passages quoted from the Politics, and, moreover, because Aristotle is rather lucid on what he claims is the instrumental nature of true wealth, the natural limit not only "exists" but stands in direct relation to his account of the good life.

Why, then, is there confusion over the putatively questionable existence of the natural limit and, moreover, why have some scholars attempted to disconnect the natural limit from Aristotle's ethics? It seems that part of the confusion over Aristotle's natural limit derives from the contingency of the limit. S. Todd Lowry $(1974,61)$ has argued that the natural limit is contingent on a person's use of wealth: "As long as money is sought only for the object of buying goods to be used, the constraints of the natural limit of desire operate." If this were true, then Aristotle's natural limit would only operate if the master restricted his wealth acquisition to a peculiar sort and level: to those objects that are useful for administering the oikos. For every other instance, where the objects of wealth are used in exchange (a practice that Aristotle believes is almost always characteristic of commercial or trade activities), the natural limit would not be operational. This reading, however, fails to recognize that Aristotle defines the limit in relation to his objective account of the good life whereby the constraint on wealth acquisition applies generally to humans capable of achieving eudaimonia (adult free male citizens). Under this view, Aristotle's natural limit cannot be contingent on any person's subjective choice to acquire or use wealth in any particular way, but on their 
being a member of the human species. Thus, a virtuous person who manages the oikos will respect the natural limit while a non-virtuous person may exceed it.

Other scholars acknowledge the existence of the natural limit but question whether unnatural money-making might be expurgated from the ethical sphere altogether. For example, as a part of his main claim that Aristotle's economic writings in the Nichomachean Ethics fail to meet certain criteria of economic analysis, ${ }^{11}$ Finley (1970) argues that because Aristotle's ethics has a natural basis and unlimited money-making is unnatural, the latter is not a subject for ethical discourse. He further adds that the acquisition of money beyond the natural requirements of a household "is made 'not according to nature but at the expense of others,"12 a phrase that echoes in reverse the 'each has his own' of the Ethics and gives the final proof that commercial exchange was not the subject in the Ethics" (17). This confusing statement apparently indicates that Aristotle's Nichomachean Ethics can be effectively described by the phrase "each has his own," and that this is evidence for demonstrating that the text does not concern unnatural chrêmatistikê. But if this phrase is meant to portray Aristotle's virtue ethics as an individualist kind of ethical theory, then Finley is mistaken. The Nichomachean Ethics is, of course, replete with discussion of the social excellences, namely, the preeminent excellence of justice. Furthermore, virtues such as courage, moderation, munificence, and open-handedness not only benefit the virtuous individuals who possess them but are positively connected to the welfare of others. ${ }^{13}$

The idea of a detachment between Aristotle's natural limit and his account of the good life is also explored by Lowry (1974, 60; 1987, 232-36) when he criticizes W. L. Newman ([1887] 1950) for associating "the natural limit with a concept of virtue deduced from the hypothetical good life." Lowry suggests the possibility that Aristotle's concept of natural limit might be explained by reference to naturalistic and materialistic termswithout the need for moral terms. ${ }^{14}$ This view is puzzling, however, since Aristotle's ethical theory is itself naturalistic: the good or flourishing of any

11. Finley ([1973] 1999, 21) claims that Aristotle "wrote no Economics" (italics in the original).

12. Here, Finley cites Pol 1258b1-2.

13. This is true even if the virtues remain primarily individualistic.

14. Newman claims that oikonomikê is a practical science. He states, "The household must be placed under the authority of a head who knows that the quest of commodities should be kept within the limits which the interests of virtue and happiness impose" ([1887] 1950, 127). 
creature with a particular nature, including humans, necessarily requires living up to that nature.

Contrary to the views considered by Finley and Lowry, Aristotle's natural limit cannot be properly understood without references to Aristotle's ethical thought; rather, the natural limit is inextricably linked to his account of human flourishing or eudaimonia. In addition to the passages from Aristotle's writings considered already, one need not look too far for more evidence to support this claim. In the passage of the Politics where Aristotle refers to Solon's poem (cited above), he makes a clear connection between a limit on the one hand, and the role of that limit in relation to the good life on the other. In book 6 of the Nichomachean Ethics, Aristotle baldly states, "Perhaps one's well-being is inseparable from managing a household" (NE 1142a9-10). ${ }^{15}$ In the Politics, while alluding to the erroneous ways of unnatural pleasure-driven chrêmatistikê, Aristotle again reinforces the relationship between oikonomikê and living well or the good life. He states,

Some persons are led to believe that getting wealth is the object of household management, and the whole idea of their lives is that they ought either to increase their money without limit, or at any rate not to lose it. The origin of this disposition in men is that they are intent upon living only, and not upon living well. (Pol 1257b38-1258a1)

While the distinction Aristotle makes between natural and unnatural chrêmatistikê is essential to the intelligibility of the natural limit, it cannot, on its own, provide an adequate account of the concept. Unnatural chrêmatistikê goes beyond what is required for oikonomikê and exceeds the limit of true wealth, the level of wealth requisite for the good life. Therefore, a satisfactory account of Aristotle's natural limit will clarify how chrêmatistikê and household management are consistent with Aristotle's virtue ethics, and this requires understanding the interplay between Aristotle's ethical theory, oikonomikê, and the acquisition of true wealth.

For Aristotle, the self-sufficiency of a household is sometimes understood as "autarky," "independence from others," "lacking in nothing," or "getting enough" (Meikle 1995). If the meaning of self-sufficiency is understood as "getting enough" (or indeed, any of the other meanings as

15. All references to Aristotle's Nichomachean Ethics refer to Christopher Rowe's translation (Broadie and Rowe 2002). 
well), then surely this gives rise to a crucial question: getting enough for what? While taking action to acquire the set of useful objects or true wealth is a basic concern for the master of any household, it would be folly to conclude that such an acquisition is the final end of humans engaged in oikonomikê. For Aristotle, although any good human life requires the natural associations of households and a polis, the ultimate end is eudaimonia or the Chief Good. In The Household as the Foundation of Aristotle's Polis, D. Brendan Nagle $(2006,91)$ states,

Autarky is not limited to the satisfaction of mere material needs. Human flourishing can only be achieved in a setting in which the household and political community are integrated as a single entity, each interacting with and sustaining one another. Without the fundamental relationships that a household provides and nourishes, the individual cannot flourish.

Seen in this light, from the viewpoint of human lives on the whole, the self-sufficiency of households is a necessary, although intermediary, step along the road to eudaimonia. Good oikonomikê results in a self-sufficient oikos. Such an oikos will not only provide the subsistence needs of each household member, but for those individuals capable of achieving eudaimonia, the household's true wealth will also confer the basis for pursuing those nonpecuniary goods that Aristotle tells us are necessary conditions for the good life. ${ }^{16}$

\section{The "Money-Making Eudaimôn"?}

So far, this essay has argued that oikonomikê is invariably tied to eudaimonia. It should be clear that, for Aristotle, the final end of human life does not require unlimited amounts of wealth. Eudaimonia is discussed at length toward the beginning of the Nichomachean Ethics and is famously considered by Aristotle to be the summum bonum - the ultimate end of

16. The present article is only concerned with individuals whom Aristotle considers capable of achieving eudaimonia. For Aristotle, only the ruling free men who head households need complete virtue of character. Although women have the capacity for deliberation, this capacity is without authority (see book 1, chapter 13 of the Politics), which, as Roberts (2009) explains, means that women can think of their good and how they might attain it but that deliberation is not in their full control. Both women and children can achieve virtue relative to their inferior souls (Pol, 1260a 20-4). Slaves, on the other hand, lack practical wisdom, the capacity to deliberate, and they also have an inferior rational part of the soul (Miller 1995). For more on Aristotle's account of the nature of women, see Smith 1983. 
human life that is inclusive of all intrinsically valuable goods. ${ }^{17}$ In book 1 of the Nichomachean Ethics, Aristotle describes eudaimonia as complete without qualification and therefore "always desirable in itself and never because of something else." The eudaimôn is a "blessedly happy" and flourishing human being who possesses the human excellences, and therefore possesses the right kinds of dispositions (virtues) when it comes to action. As J. L. Ackrill $(1980,22)$ states, "(1) you cannot say of eudaimonia that you seek it for the sake of eudaimonia; (2) you cannot say you would prefer eudaimonia plus something extra to eudaimonia." Given this rigorous definition of the good life, objections to its being the final end of human life are immediately strained: one is compelled to argue that the final end of human life is somehow not the best life imaginable but rather an inferior life of sorts, one composed of less rather than more of the intrinsically valuable goods.

In the remaining sections of this essay, it is argued that if an individual treats money-making as an end in itself, unconstrained by the needs of his household, he cannot be eudaimôn. The main question to be investigated is whether, for Aristotle, it is feasible for any agent to engage in moneymaking while simultaneously living a flourishing human life. To put it another way, are there eudemonic individuals who are also engaged in money-making as an end in itself? Three reasons are given to deny this prospect. For Aristotle, money-making as an end in itself is endemic to the life of pleasure, not the good life; action directed toward the pursuit of ever-more money is likely to crowd out other intrinsically valuable goods; and finally, wealth acquisition beyond the natural limit is excessive from the standpoint of Aristotle's Doctrine of the Mean.

\section{Money-Making and the Life of Pleasure}

Aristotle associates the unnatural money-maker's goal of accumulating an ever-larger pile of money with the life of pleasure. In the Politics, he states,

Those who do aim at a good life seek the means of obtaining bodily pleasures; and, since the enjoyment of these appears to depend on prop-

17. This is, arguably, the most common interpretation of eudaimonia. Thomas Nagel (1980) describes the competing intellectualist account of human flourishing (derived mostly from book 10 of the Nichomachean Ethics) whereby eudaimonia is realized in the activity of theoretical contemplation. For more on this second interpretation, see Richard Kraut's (1989) Aristotle on the Human Good. These two accounts of eudaimonia are sometimes referred to as the "inclusive" and "dominant end" conceptions (see Hardie 1965). 
erty, they are absorbed in getting wealth: and so there arises the second species of wealth-getting. For, as their enjoyment is in excess, they seek an art which produces the excess of enjoyment. (Pol 1258a3-7)

This quotation suggests that Aristotle not only links the second species of wealth-getting, unnatural chrêmatistikê, with pleasurable things but that he believes the basis or motivation for individuals to engage in such pursuits is bodily pleasures. The reference to "excess" in combination with unnatural chrêmatistikê and pleasure is also telling; according to Aristotle's Doctrine of the Mean, excess and deficiency always reveal a defect in one's character.

Although Aristotle recognizes that pleasure, with certain qualifications, is itself an intrinsically valuable good (for him it is difficult to imagine any life worthy of the name "good" without any pleasure whatsoever),${ }^{18}$ he argues against identifying pleasure with eudaimonia. J. L. Ackrill (1980, 21-22) describes why pleasure, for Aristotle, must be a subset of all intrinsically valuable goods within the realm of eudaimonia. Although one can answer the question "Why do you seek pleasure?" by stating that you seek it as an element in the most desirable sort of life, one cannot be expected to answer the question "Why do you seek the most desirable sort of life?," at least not in the same way. This does not imply that pleasure is not intrinsically worthwhile, but only that it is a means to an end. It is partly the instrumental quality of pleasure itself that is a reason why eudaimonia is not "just pleasure." Moreover, for Aristotle, pleasure is an intrinsically valuable good but not at all times and in all situations. It bears this quality for individuals only when it is the consequence of taking the right kinds of actions in the right circumstances, something that the humanly excellent individual performs invariably.

Aristotle's function (ergon) argument, originally put forward in book 1, chapter 7, of the Nichomachean Ethics, is highly relevant to the connection he draws between unnatural chrêmatistikê and the life of pleasure. The conclusion of this argument implies that the good of any kind of being ultimately resides in its function. For Aristotle, to know the good of a quality, for example, depends on the substance at hand, and in the case of humans, there is a normative natural goodness for the kind of being a human is. Whatever a good human life proves to be, it certainly has to be characteristic of human beings, or as Martha Nussbaum $(1995,112)$

18. Living well involves pleasure because the virtuous individual finds it satisfying to live up to his ideals (see the Nichomachean Ethics, 1.8). 
explains, "A good active life for a being must first of all be a life for that being-i.e. it had better include those activities that are essential to, definitive of, that sort of being."

Aristotle asks, then, what it is that humans characteristically do and whether there is an essential quality belonging to humans without which the members of this class would lack a distinctive nature. After acknowledging that humans share just about everything in common with other plants and animals, Aristotle concludes that the unique and highest-order functioning of humans is their capacity for reasoning or deliberation, a function that he attributes to the immaterial human soul. Therefore, the life of mere pleasure for human beings misses the mark for humans (save slaves) because it fails to demand of humans the full exercise of their practical and theoretical reasoning. Indeed, Aristotle thinks that for humans to pursue the life of pleasure, wrongly conflating it with the good life, is to accept a mindless life, one that is available to "grazing cattle" (NE 1095b21). In such a case, Aristotle states, "there wouldn't be any difference being born a beast and a human being" (Nussbaum 1995, 116).

Aristotle also employs his function argument against those who would direct all of their human faculties toward the goal of attaining ever-more pleasure. For Aristotle, such a move is contrary to the multifarious ergon of human faculties. In the Politics, for example, he states,

If they are not able to supply their pleasures by the art of getting wealth, they try other causes, using in turn every faculty in a manner contrary to nature. The quality of courage, for example, is not intended to make wealth, but to inspire confidence. . . . Nevertheless, some men turn every quality or art into a means of getting wealth; this they conceive to be the end, and to the promotion of the end they think all things must contribute. (Pol 1258a8-14)

If treating money-making as an end in itself is symptomatic of a life directed at pleasure, then it is difficult to see how, for Aristotle, such a pleasure-seeking life can also be eudaimôn, since Aristotle clearly objects to the hedonist's identity thesis. It remains to be answered, however, whether the money-maker might respond by claiming that he pursues endless riches as an end in itself (as detailed in the previous quote), thus denying Aristotle's claim that it is for pleasure or even the life of pleasure that he engages in such projects. If one follows Ackrill's $(1980,21)$ interpretation of eudaimonia as "the most desirable sort of life, the life that contains all intrinsically worthwhile activities," then such a money-maker would 
have to explain how unnatural chrêmatistikê is an intrinsically worthwhile activity. If such an objection were compelling it would point to a serious omission on Aristotle's part, for it would imply that unlimited moneymaking is somehow valuable in itself. Unlimited money-making would then have to become a part of the good life prescribed by Aristotle. But Aristotle offers a simple rebuttal to silence this objection. As discussed earlier, he highlights the instrumental role of money, thus denying any claim to its intrinsic worth: "The life of the money maker is of a sort that is chosen under compulsion of need, and wealth is clearly not the good we are looking for, since it is useful, and for the sake of something else" ( $N E$ 1096a5-8).

\section{The Crowding-out Effect of Money-Making}

Another reason to deny that an individual might pursue boundless moneymaking and simultaneously live a flourishing life is discussed at length by William James Booth (1993) in his Households: On the Moral Architecture of the Economy. Although he does not argue in such explicit terms, in effect he claims that a life devoted to money-making beyond the needs of one's household can restrict or crowd out other intrinsically valuable goods and conditions for the good life, including leisure (scholē) time, philia, and freedom from constraint or autonomy. For these reasons, the useless objects of wealth-the ones without a use for the household - that the money-maker spends his time acquiring are not benign but can be injurious to the welfare of the person acquiring such objects. In sum, the endless activity of money-making can act as an impediment to what might otherwise be a flourishing human life.

To understand why this is the case, we need to realize that, although the immediate objective of oikonomikê is to meet the basic needs of household members, another key purpose in acquiring true wealth involves becoming independent or free from the constraints imposed by others and nature. The acquisition of true wealth is partly a means to become selfsufficient or autarkic. Booth (1993, 44-46) argues that autarky, the freedom from necessary toil and from the restraint of others, is closely related to schole and the space leisure creates for cultivating friendships and the possibility for participating in the affairs of the polis. In the Politics, Aristotle explains that schole is better than, and is the end of, occupation, which is always accompanied with exertion and effort. Unlike the "busy man" who does not have any leisure, those who have it derive pleasure, 
happiness, and enjoyment of life from leisure itself (Pol 1337b271338a3). ${ }^{19}$ Schole is, in the main, made possible by having a self-sufficient household. As Nagle $(2006,130)$ states, "Small surpluses were necessary, but the aim of farming was not to produce large surpluses for an export market. The properties should be sufficient to supply enough goods to sustain the citizen and his family in leisure." If self-sufficiency implies having enough for the good life, as I have argued above, and if leisure is an intrinsically valuable good that is required for the good life, then a selfsufficient household endowed with true wealth will also provide leisure time for its free members. The master whose household is entirely autarkic will have the leisure time available to choose whether or not to pursue praxis and other intrinsically valuable goods. Leisure is made possible by acquiring sufficient true wealth, that is, enough to grant the free members of a household with the good fortune of participating in valuable activities, activities that go beyond economically necessary actions.

Booth underscores the importance of leisure as a basic goal for the ancient household and ties schole to philia, not only among household members, but among the members of different households throughout the city. ${ }^{20} \mathrm{He}$ states, "Leisure is necessary for both the private philia of persons hunting or philosophizing and also for the friendship of the larger community, that of the city," and "leisure is required for political praxis and excellence, just as it is for the virtues of private friendships" (1993, 46-47). For Aristotle, all friendships are characterized by mutual liking: a friend is someone who likes and is liked by another person. ${ }^{21}$ In the Eudemian Ethics, he distinguishes three types of friendship: for virtue (kat'aretên), for utility (kata to chrêsimon), and for pleasure (kata to $h \hat{e} d u){ }^{22}$ The first type, sometimes referred to as character friendships, is essential for achieving eudaimonia. Their primary purpose is to develop the moral goodness of each person involved in the relationship (see Cooper 1980). These relations are exceptional and involve well-wishing that is fully reciprocated between the parties involved. They are also grounded in knowledge of and love of one another's good qualities of character. On the

19. Aristotle also recognizes that men are busy in order to have leisure (see book 10, chapter 7, of the Nichomachean Ethics [1177b5]). It is worth recognizing that in Plato's Phaedo (66d) Socrates recognizes leisure as a necessary condition for doing philosophy (Cooper 1997).

20. Booth (1993, 31-32) states that "[household management] aims at something more than the satisfaction of material wants: its object is also to preserve, as far as possible, the household's philia, the common bond and purpose of its free members, against the intrusions of constraint and necessity which are an essential part of the reproduction of human livelihood."

21. See the Rhetoric (1380b36-1381a2) in Barnes [1984] 1995.

22. See the Eudemian Ethics (7.10, 1242b2-3) in Barnes [1984] 1995. 
other hand, utility and pleasure friendships are, on the whole, less enduring than character friendships. The former (for example, business relations) ceases to exist when the advantages of the relationship end, while pleasure friendships merely involve loving another person for their incidental features-not for their character.

In fact, Aristotle dedicates a significant portion of the Nichomachean Ethics (especially books 8 and 9) to the topic of friendship and elaborates on the direct connection character or virtue friendships have for eudaimonia. In these chapters, Aristotle affirms that such friendships are "very necessary for living" and that "no one would choose to live without friends" (NE 1169b10); in book 9 he affirms that friends seem to be the greatest of external goods. John M. Cooper (1980, 317-18) argues that, for Aristotle, friends are good "as such" for human beings, implying that their value is not exhausted in terms of instrumental values alone; on the contrary they are a necessary condition for a flourishing human life. In fact, Cooper goes so far as to argue that Aristotle's theory of virtue cannot be completely understood unless read in light of the chapters on friendship.

But why would the eudaimôn, if he is indeed eudemonic, need something else, including friends, if the good life is, by definition, complete? Cooper argues that the eudaimôn needs self-knowledge, and the most comprehensive way to acquire and maintain such knowledge of the self is through character friendships. If one accepts Cooper's interpretation of Aristotle's claim that self-knowledge is a feature of authentic characterfriendships and that it is, therefore, an intrinsically valuable constituent of the good life, then one can begin to appreciate why Aristotle emphasizes the creation of leisure time as a main purpose for the oikos.

It is easy to imagine a life wholly committed to money-making as an end in itself, one that involves undue time commitment. Such a life will be prone to a crowding-out effect that results in a severe diminishment of one's overall leisure time; and, if schole is a precondition for friendship in general and character friendships in particular, then any such individual who finds himself bound to a project without end, such as money-making beyond the needs of one's household, is likely to forego these intrinsically valuable human associations.

A characteristic feature of a self-sufficient oikos is that all of the free members have become autonomous. For the master who chooses to pursue unnatural chrêmatistikê, autonomy may be available, but he forgoes the opportunity and replaces it with a project that is both endless and insatiable. The individual engaged in perpetual action directed toward a project without end surrenders his autonomy by becoming a "slave to 
money-making." Describing a passage from Xenophon's Oeconomicus, Booth $(1993,49)$ states, "Those who do not rule their households with the purpose in mind of securing the good life may have many possessions but it is as if they are themselves governed by Xenophon's 'invisible masters' in their quest after still more wealth." ${ }^{23}$ Such a life is unleisured because its demands are never ending and, moreover, it is led under constraint. Indeed, Aristotle explicitly states that "the life of the money maker is of a sort that is chosen under compulsion of need" (NE 1096a5-6). ${ }^{24}$ Not only can unlimited wealth acquisition lead to the loss of the money-maker's overall freedom, autonomy, and other intrinsically valuable goods that could have been afforded with less wealth but, as Booth suggests, the money-maker develops a disposition toward the excess of pleonexia. Such excesses are vices for Aristotle, and, as a consequence, the efforts of our so-called money-making eudaimôn are hindered ever more.

\section{Unlimited Money-Making as an Excess}

For individuals aiming at the good life, unnatural chrêmatistikê is an illadvised activity, for it is not an aim of the practically wise (phronimos) who is eudaimôn because he possesses the human excellences..$^{25} \mathrm{~J}$. O. Urmson (1980) interprets Aristotle's account of good and bad character in the Nichomachean Ethics as the Doctrine of the Mean, whereby the individual endowed with phronēsis and an excellent character will choose the right action, the mean. This intermediate or midway position can be thought of as a point along a continuum between deficiency, on the one hand, and excess on the other. ${ }^{26}$ Excess and deficiency flank "each side" of the excellences, like courage, moderation, greatness of soul, open-handedness, etc. Not only does the phronimos' actions display mean states, but as

23. Referring to Xenophon's Oeconomicus, I.18ff, Booth suggests that the "invisible master" ruling over Kritoboulus (Socrates's main interlocutor) is pleonexia. In Oeconomicus, I.22ff, Socrates describes slaves who are ruled by "harsh masters." Some such slaves are "ruled by gluttony, some by fornication, some by drunkenness, and some by foolish and expensive ambitions which rule cruelly over any men they get into their power" (see Pomeroy 1994). The point that is being made by Socrates is that if one becomes a slave to such a master, then goods and money can destroy one's body and soul.

24. Quoting the same passage from the Nichomachean Ethics, Finley $(1970,14)$ translates Aristotle as stating, "The money-maker is someone who lives under constraint."

25. J. O. Urmson $(1980,160)$ states, "Excellence of character is . . that state of character which entitles a man to be called eudaimōn."

26. As Sarah Broadie (2002) describes, human excellence is an unconditional preparedness to act, feel, and in general respond in the ways typical of the humanly excellent person. 
Urmson (1980) suggests, the individual with an excellent character will also display the mean emotional and choice states as well. In other words, the individual possessing human excellence will be wise enough to consistently choose the right actions in potentially dissimilar contexts and will also want to do the right action and derive pleasure from it.

For Aristotle, failing to choose the mean or particular excellences in a given situation reveals a defective character. But while this is a common interpretation of Aristotle's Doctrine of the Mean, it is not strictly true, since successfully choosing the intermediate does not necessarily imply that an agent has an excellent character. ${ }^{27}$ An agent may be sufficiently disciplined to take the right action-the same action as the phronimos-but he might simultaneously fail to manifest the right kind of emotional response. This describes the profile or character of the individual with "self-control." The other two character-types described by Urmson (1980, 163), in increasing order of badness, are individuals who "lack self-control" and those who possess "badness of character." The former is capable only of choosing in the same manner as the phronimos but fails to display the mean emotional and mean action states, while the latter, the worst character of all, fails to display all of the mean states: emotional, action, and choice.

The virtue of particular relevance to Aristotle's natural limit and wealth acquisition is open-handedness, the intermediate state regarding the giving and receiving of money. In book 4 of the Nichomachean Ethics, Aristotle describes the open-handed person in the following passage:

Things that have a use can be used both well and badly; wealth is something that has a use; and each thing is used best by the person possessing the excellence relating to that thing: wealth, then, too, will be used best by the person possessing the excellence relating to money, and this is the open-handed person. (NE 1120a5-8)

Because he possesses the excellences, the phronimos will act rightly and will choose the intermediate of open-handedness. Aristotle explains that "wisdom is a disposition accompanied by rational prescription . . . in the sphere of human goods, relating to action" (NE 1140b20-23). Individuals of defective character, especially those who lack self-control or possess a bad character, will display a deficiency or excess with respect to the virtues. Actions directed toward endless wealth acquisition, representing the

27. For a challenge to Urmson's interpretation of Aristotle's Doctrine of the Mean, see Hursthouse 1980-81. 
desire for an unfairly large share of distributable goods, are considered bad because such actions are a form of excess-avariciousness-and thus, a vice. If the phronimos is eudaimon because his character is not defective in such ways, then it would seem that actions directed toward excessive money-making would be, at the very least, inauspicious for the would-be money-making eudaimôn. Indeed, Griswold $(1999,266)$ goes even further, stating that "commerce unregulated by a vision of the good or virtuous life destroys the character of the citizens."

One might object to my argument by claiming that generosity, or what Aristotle terms "munificence" in book 4 of the Nichomachean Ethics, seems to involve expenditure that extends beyond oikonomikê. It might seem prima facie that if one is obliged to engage in such seemingly extraneous expenditures, the natural limit would not apply. However, because munificence is itself a virtue, it is also governed by the Doctrine of the Mean and is therefore flanked by deficiency and excess (in this case, shabbiness and tastelessness, respectively). Although munificence may involve expenditure that extends beyond oikonomikê, the virtuous person may engage in such expenditures, but only on a suitable scale that is both relative to the person concerned and the specific context at hand.

Another worry is that, while the money-maker may possess a defective character with respect to the virtue of open-handedness, he may nonetheless possess some or even all of the other Aristotelian virtues, and thus, it would seem hardly fair to deny the possibility of a money-making eudaimôn. Moreover, one might question a life that is only "partly" committed to unnatural chrêmatistikê. The claim defended in this article is that, for Aristotle, endless wealth acquisition is an activity that goes beyond acquiring true wealth and that pleonexia will always hinder or work against the money-maker's ambition to also become eudaimôn, instead of facilitating what might otherwise be a fully flourishing life.

\section{Conclusion}

This essay has argued that Aristotle's natural limit is inseparably tied to his ethical theory, implying as it does that true wealth is "having enough" useful objects of wealth for household management and, ultimately, for the good life. Moreover, for Aristotle, an individual who treats money-making as an end in itself cannot simultaneously attain eudaimonia or live a flourishing human life. Three reasons were given to support this claim. First, Aristotle associates the unnatural and unlimited project of money-making 
with the life of pleasure, not the good life. Given Aristotle's function argument and his dismissal of the life of pleasure as the best life available to humans, it is difficult to see how one who perpetually engaged in unnatural chrêmatistikê could also achieve eudaimonia. Second, following Booth (1993), it was argued that a life devoted to money-making independent of the needs of one's household can crowd out or even restrict other intrinsically valuable goods such as philia and autonomy that Aristotle deems necessary for achieving eudaimonia. Third, according to Aristotle's Doctrine of the Mean, activities directed at unnatural chrêmatistikê are simply the wrong aim for anyone striving for the good life. Limitless wealth acquisition is closely related to the excess of the virtue of open-handedness, pleonexia, and therefore it is not an objective pursued by the practically wise phronimos in possession of the human excellences. In fact, displaying pleonexia reveals a deficit in character and is a form of badness that moves the money-maker further away from attaining eudaimonia.

While these reasons were marshalled as evidence to negate the proposition that Aristotle would accept the notion of a money-making eudaimôn, one might persist by objecting that unnatural chrêmatistikê is or could really be independent of the good life. Of course, this essay has already argued to the contrary. But to respond even further, it would certainly be surprising if, on Aristotle's account, human action directed toward excessive money-making always had a deleterious effect on one's well-being and yet unnatural chrêmatistikê was still somehow independent of the good life. Therefore, one of the main conclusions defended in this article, that Aristotle would deny the possibility of a money-making eudaimôn, is itself more evidence for the specific interpretation of Aristotle's natural limit defended in this essay.

\section{References}

Ackrill, J. L. 1980. “Aristotle on Eudaimonia.” In Essays on Aristotle's Ethics, edited by Amélie Oksenberg Rorty, 15-33. Berkeley: University of California Press.

Barnes, J., ed. (1984) 1995. The Complete Works of Aristotle. Princeton, N.J.: Princeton University Press.

Booth, W. J. 1993. Households: On the Moral Architecture of the Economy. Ithaca, N.Y.: Cornell University Press.

Broadie, S. 2002. "Philosophical Introduction." In Nichomachean Ethics, translated by Sarah Broadie and Christopher Rowe, 9-91. Oxford: Oxford University Press.

Broadie, S., and C. Rowe, eds. 2002. Nichomachean Ethics. Oxford: Oxford University Press. 
César das Neves, J. 2000. “Aquinas and Aristotle's Distinction on Wealth.” History of Political Economy 32:649-57.

Collingwood, R. G. (1945) 1976. The Idea of Nature. New York: Oxford University Press.

Cooper, J. M. 1980. “Aristotle on Friendship.” In Essays on Aristotle's Ethics, edited by Amélie Oksenberg Rorty, 301-40. Berkeley: University of California Press.

—, ed. 1997. Plato: Complete Works. Cambridge, Mass.: Hackett.

Finley, M. I. 1970. “Aristotle and Economic Analysis.” Past and Present 47:3-25.

—. (1973) 1999. The Ancient Economy. Berkeley: University of California Press.

Griswold, C. 1999. Adam Smith and the Virtues of Enlightenment. Cambridge: Cambridge University Press.

Hardie, W. F. R. 1965. "The Final Good in Aristotle's Ethics.” Philosophy 40:277-95.

Hursthouse, R. 1980-81. "A False Doctrine of the Mean." Proceedings of the Aristotelian Society, n.s., 81:57-72.

Kaye, J. 1998. Economy and Nature in the Fourteenth Century. Cambridge: Cambridge University Press.

Kern, W. 1983. "Returning to the Aristotelian Paradigm: Daly and Schumacher." History of Political Economy 15:501-12.

Kraut, R. 1989. Aristotle on the Human Good. Princeton, N.J.: Princeton University Press.

Lowry, S. T. 1974. "Aristotle's 'Natural Limit' and the Economics of Price Regulation." Roman and Byzantine Studies 15:57-63.

— 1987. The Archaeology of Economic Ideas. Durham, N.C.: Duke University Press.

Meikle, S. 1994. “Aristotle on Money.” Phronesis 39:26-44.

- 1995. Aristotle's Economic Thought. Oxford: Clarendon Press.

Miller, F. D. 1995. Nature, Justice, and Rights in Aristotle's "Politics." Oxford: Clarendon Press.

Nagel, T. 1980. “Aristotle on Eudaimonia.” In Essays on Aristotle's Ethics, edited by Amélie Oksenberg Rorty, 7-14. Berkeley: University of California Press.

Nagle, D. B. 2006. The Household as the Foundation of Aristotle's Polis. Cambridge: Cambridge University Press.

Newman, W. L. (1887) 1950. The Politics of Aristotle. Vol. 1. Oxford: Clarendon Press.

Nussbaum, M. 1995. "Aristotle on Human Nature and the Foundations of Ethics." In World, Mind, and Ethics: Essays on the Ethical Philosophy of Bernard Williams, edited by J. E. J. Altham and Ross Harrison, 86-131. Cambridge: Cambridge University Press.

Pack, S. J. 1985. "Aristotle and the Problem of Insatiable Desires: A Comment on Kern's Interpretation of Aristotle, with a Reply by William S. Kern.” History of Political Economy 17:391-94.

Pomeroy, S. B. 1994. Xenophon, Oeconomicus: A Social and Historical Commentary. Oxford: Clarendon Press.

Roberts, J. 2009. Routledge Philosophy Guidebook to Aristotle and the "Politics." London: Routledge. 
Smith, N. D. 1983. "Plato and Aristotle on the Nature of Women." Journal of the History of Philosophy 21:467-78.

Urmson, J. O. 1980. “Aristotle's Doctrine of the Mean.” In Essays on Aristotle's Ethics, edited by Amélie Oksenberg Rorty, 157-70. Berkeley: University of California Press.

West, M. L. 1972. Iambi et Elegi Graeci ante Alexandrum cantati. Vol. 2, Callinus Mimnermus, Semonides, Solon, Tyrtaeus, Minora adespota. Oxford: Clarendon Press. 
